\title{
Рівень летальності хворих з пухлинами зовнішніх статевих органів при ретроспективному 25-річному спостереженні, роль клінічного стадіювання в прогнозуванні віддаленої летальності
}

\author{
Національний інститут раку, Київ \\ Отримано 16.08.2020 \\ Прийнято до друку 1.09.2020 \\ DOI: $10.32471 /$ clinicaloncology.2663-466X.39-3.27419
}

\begin{abstract}
Матеріал та методи дослідження. Стаття базується на 25-річному ретроспективному спостереженні та присвячена аналізу рівня летальності пацієнтів з пухлинами зовнішніх статевих органів, прогнозуванню віддаленої летальності залежно від клінічних особливостей пухлин. Робота проводилася на базі Національного інституту раку з включенням вивчення 557 іс-

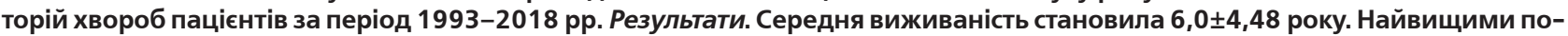
казниками загальної смертності характеризувалися пацієнти з IVA та IVB стадіями захворювання за шкалою Міжнародної федерації гінекології та акушерства (International Federation Gynecology and Obstetrics - FIGO; при IVB стадії виключення з дослідження було розподілено рівномірно на весь період спостереження, при IVA стадії пацієнти вибували за рахунок летальності вже на першому році. Доведено приріст загальної виживаності після 2010 р. для I та II стадій захворювання. 3начний приріст летальності за критерієм Т відмічено при переході до Т3 та Т4 (74,4 та 100,0\% відповідно), найнижчий показник загальної смертності відмічено при локальних пухлинах (Tis - 5,6\%). Встановлено зростання частоти загальної летальності при N1 та N2 (80,0 та 81,5\% відповідно), порівняно з N0 (44,7\%, p<0,05). При NX рівень летальності був на 12,0\% вищим, ніж при критерії N0. Висновки. Загальна смертність за наявності віддалених метастазів (M1) на 33,7\% перевищувала таку, яка встановлена за відсутності метастазів (М0). Після 2000 р. в Національному інституті раку було відмічено підвищення якості діагностики відносно критерію MX, проте за критерієм NX покращення якості діагностики не виявлено.
\end{abstract}

Ключові слова: пухлини зовнішніх статевих органів; клінічне стадіювання; віддалена летальність; прогноз.

\section{АКТУАЛЬНІСТЬ}

Внаслідок особливостей анатомо-топографічної будови, зокрема завдяки надзвичайно розвиненій мережі лімфатичних судин, пухлини зовнішніх статевих органів мають схильність до раннього метастазування та швидкого прогресування [1, 2].

Основною проблемою при цьому захворюванні є пізнє звернення пацієнтів до лікувальних закладів - внаслідок малосимптомного перебігу більше як 60,0\% пацієнтів звертаються при III-IV стадіях хвороби, що значно знижує ефективність лікування. I, якщо раніше ця патологія переважно спостерігалася у жінок у клімактеричний та постменопаузальний періоди, то на сьогодні почастішали випадки діагностування даної патології у жінок репродуктивного віку [3, 4].

Основними завданнями клініциста є верифікація діагнозу, визначення прогнозу захворювання та планування найбільш ефективного курсу лікування, для чого потрібна об’єктивна оцінка анатомічного поширення ураження [5]. Із цією метою необхідно мати класифікацію, основні принципи якої могли б застосовуватися до всіх локалізацій злоякісних пухлин, незалежно від планового лікування, і яку згодом можна було б доповнити відомостями, отриманими при патогістологічному дослідженні чи даними хірургічного втручання [6].

Класифікації пухлин зовнішніх статевих органів базуються на кількох принципах: локалізації пухлини, клінічному або патологічному поширенні ураження, тривалості симптомів або ознак, статі та віку пацієнтів, гістологічній будові, ступені злоякісності $[5,7]$. Усі ці ознаки певною мірою впливають на прогноз перебігу захворювання та водночас не дають повної оцінки. Також оцінка лімфонодального статусу - важливий етап у плануванні лікування $[8,9]$. Класифікація TNM грунтується, передусім, на прогнозі. У численних дослідженнях було вивчено залежність виживаності від поєднання різних критеріїв Т, N і М [10, 11].
Проте дослідження хронологічних особливостей виживаності у пацієнтів з раком зовнішніх статевих органів залежно від діагностичних можливостей онкогінекології в нашій країні, фактично, не проводилися.

Тому метою роботи було вивчення особливостей летальності пацієнтів з пухлинами зовнішніх статевих органів при ретроспективному 25-річному спостереженні, а також ролі клінічного стадіювання в прогнозуванні віддаленої летальності впродовж тривалого періоду спостереження.

\section{МАТЕРІАЛ ТА МЕТОДИ ДОСЛІДЖЕННЯ}

Робота проводилася на базі Національного інституту раку (Київ). В основі роботи - 25-річне ретроспективне спостереження з вивченням 557 історій хвороб пацієнтів та виписних епікризів. Віддалений період з аналізом наслідків клінічного перебігу простежено у пацієнтів, що лікувалися на базі Національного інституту раку у 1993-2018 pр.

Середній вік пацієнтів становив $62,3 \pm 13,2$ року (18-90 років): старше 75 років - 185 випадків $(33,2 \%), 60-75$ років 160 випадків $(28,7 \%), 44-60$ років - 139 випадків $(24,9 \%)$, молоді жінки (25-44 роки) - 60 випадків $(10,8 \%)$, підлітки 13 осіб $(2,3 \%)$.

Однією з кінцевих точок дослідження було вивчення загальної летальності.

Для статистичного аналізу отриманих результатів використовували пакет програм обробки даних загального призначення Statistica for Windows версії 7.0 (Stat Soft inc., США) та SPSS 17.0. Дискретні величини представлені у вигляді частот (відсоток спостережень до загальної кількості обстежених). Для порівняння дискретних величин у незалежних групах використовували критерій $\chi^{2}$ Пірсона. Оцінка ризику настання несприятливої події проводилася з урахуванням абсолютного (absolute risk - AR) та відносного (relative risk $\mathrm{RR}$ ) ризиків, а також відношення шансів (odds ratio - OR), 
з розрахунком довірчих інтервалів та критерію достовірності щодо RR та OR [12].

Аналіз летальності проводився за допомогою аналізу Каплана - Мейєра з розрахунком логранк критерію і показника відносного ризику між кривими дожиття - HR (hazard ratio), оцінкою показників - медіан часу виживаності, експоненційних медіан тривалості випадку і частот ускладнень.

При $\mathrm{p}<0,05$ розбіжності вважали статистично вірогідними.

\section{РЕЗУЛЬТАТИ ДОСЛІДЖЕННЯ}

Розподіл пацієнтів ретроспективної групи за стадією відповідно до класифікації FIGO наведено в табл. 1. Встановлено, що раннє звернення при пухлинах зовнішніх статевих органів становило менше третини клінічних випадків - стадію I встановлено у 26,3\%, IA - у 2,7\%, IB - у 1,4\% пацієнтів. Найбільша кількість пацієнтів вперше зверталися на II стадії захворювання за класифікацією FIGO (40,4\%). При цьому 29,2\% зверталися з приводу первинного лікування на III та IV стадіях захворювання.

За критерієм Т класифікації TNM у найбільшої кількості пацієнток при первинному зверненні виявляли Т2 стадію, у $15,4 \%$ - Т3 стадію; 75,4\% надходили без ознак метастазування в регіонарні лімфатичні вузли $(75,4 \%)$ та ознак віддаленого метастазування $(90,8 \%)$ (табл. 2$)$.

Загальна смертність при ретроспективному аналізі пацієнтів з онкопатологією зовнішніх статевих органів в 1993-2018 рр. становила 52,2\% (291 випадок). Середня виживаність $-6,0 \pm 4,48$ року(від 0 до 36 років).

При оцінці частоти первинно діагностованого раку зовнішніх статевих органів спостерігався приріст випадків первинно виявленого раку за періоди 1998-2003 рр. та 2008-2013 рр. (табл. 3).

Виявлено характерний лінійний тренд підвищення рівня летальності в 2003-2018 pр. ( $\chi^{2}$ в тесті Кохрана - Армітеджа $-86,9 ; \mathrm{p}<0,001)$. За допомогою процедури Тьюки визна-

Таблиця 1. Розподіл хворих ретроспективної групи за стадією відповідно до класифікації FIGO при первинному зверненні

\begin{tabular}{ccc}
\hline Стадія & Кількість & $\%$ \\
\hline I & 146 & 26,3 \\
IA & 15 & 2,7 \\
IB & 8 & 1,4 \\
II & 225 & 40,4 \\
IIIA & 106 & 19,0 \\
IIIB & 27 & 4,8 \\
IVA & 12 & 2,1 \\
IVB & 18 & 3,3 \\
\hline
\end{tabular}

Таблиця 2. Стадіювання хворих ретроспективної групи за критеріями TNM при первинному зверненні

\begin{tabular}{lcc}
\multicolumn{3}{c}{ ТNМ при первинному зверненні } \\
\hline & Кількість & $\%$ \\
\hline TX & - & - \\
T0 & - & - \\
Tis & 18 & 3,2 \\
T1 & 116 & 20,9 \\
T1a & 10 & 1,8 \\
T1b & 39 & 7,0 \\
T2 & 286 & 51,3 \\
T3 & 86 & 15,4 \\
T4 & 2 & 0,4 \\
Kритерій N & & \\
NX & 30 & 5,4 \\
N0 & 420 & 75,4 \\
N1 & 80 & 14,4 \\
N2 & 27 & 4,8 \\
Критерій M & 15 & 2,7 \\
MX & 506 & 90,8 \\
M0 & 36 & 6,5 \\
M1 & &
\end{tabular}

чена статистична «точка переходу» - часовий момент, який розмежовує статистичні відмінності між показниками тимчасової шкали. У нашому випадку цією точкою був інтервал 2005-2010 pр. (оскільки різниця між частотами, що лежать зліва від цієї точки була достовірною в порівнянні з частотами, що знаходяться праворуч від цієї точки).

На наступному етапі було проведено аналіз можливих прогностичних факторів, що можуть впливати на рівень летальності.

За шкалою FIGO встановлено приріст рівня загальної смертності на 23,5\% при IVA та IVB стадіях, порівняно з I стадією, на 23,5\% відносно II стадіï, 7,3 та 11,1\% - щодо IIIA та ІІІВ стадій. Суттєво підвищувався рівень загальної смертності при переході з I до ІІ стадій за класифікацією FIGO (12,8\% - порівняно зі стадією I, 36,0\% - щодо стадії IA, на 43,5\% відносно IB стадіï) (табл. 4).

OR щодо ризику смертності вірогідно зростає при переході від I стадії (включаючи IA та IB) до стадії II (OR - 1,29), залишаючись сталим для стадій IIIA $(\mathrm{OR}-1,38)$ та IIIB $(\mathrm{OR}-1,29)$, надалі наступною межею ризику є стадії IVA та IVB $(\mathrm{OR}-1,55 ; \mathrm{p}=0,04-$ за тестом Кохрана - Армітеджа та $\mathrm{p}=0,02-$ за методом Мантеля - Хензеля) (табл. 5).

У ході аналізу хронології смертності пацієнтів було проведено множинний аналіз виживаності з використанням процедури Каплана - Мейєра (рис. 1-2).

При порівнянні стадій I та IVB з найбільшою та найменшою виживаністю було використано логранк тест, при якому $\mathrm{p}=0,01194$. Під час проведення множинного аналізу виживаності (див. рис. 2) підтверджено, що пацієнти зі стадією IVA та IVB характеризувалися найвищими показниками смертності (за кількістю померлих пацієнтів), проте, якщо при IVB стадії виключення з дослідження розподілено рівномірно впродовж усього періоду спостереження, при IVA стадії пацієнтів виключали за рахунок летальності вже на першому році спостереження. Для I та II стадій доведено приріст загальної виживаності після 2010 р., що, можливо, є свідченням більш

Таблиця 4. Рівень смертності у пацієнтів з пухлинами зовнішніх статевих органів впродовж 25-річного ретроспективного спостереження залежно від стадії за класифікацією FIGO

\begin{tabular}{ccc}
\hline Стадія & Кількість & $\%$ \\
\hline I & 63 & 43,2 \\
IA & 3 & 20,0 \\
IB & 1 & 12,5 \\
II & 126 & 56,0 \\
IIIA & 63 & 59,4 \\
IIIB & 15 & 55,6 \\
IVA & 8 & 66,7 \\
IVB & 12 & 66,7 \\
\hline
\end{tabular}

Таблиця 5. Відносна вірогідність та ризик загальної смертності у пацієнтів 3 пухлинами зовнішніх статевих органів упродовж 25-річного ретроспективного спостереження залежно від стадії за класифікацією FIGO

\begin{tabular}{lccc}
\hline \multicolumn{1}{c}{ Стадія } & OR & $\begin{array}{c}\text { Кумулятивне від- } \\
\text { ношення шансів } \\
\text { (Cumulative odds } \\
\text { ratio - COR) } \\
\text { [95\% DI] }\end{array}$ & $\begin{array}{c}\text { Узагальнене від- } \\
\text { ношення шансів } \\
\text { (Generalized odds } \\
\text { ratio - GOR) } \\
\text { [95\% дI] }\end{array}$ \\
\hline Стадія I & 1,0 & & \\
Стадія IA & 0,46 & & 1,243 \\
Стадія IB & 0,29 & 1,31 & {$[1,0-1,54]$} \\
Стадія II & 1,29 & {$[1,03-1,68]$} & \\
Стадія IIIA & 1,38 & & \\
Стадія IIIB & 1,29 & & \\
Стадія IVA & 1,55 & & \\
Стадія IVB & 1,55 & & \\
\hline
\end{tabular}

Таблиця 3. Частота первинно діагностованого раку зовнішніх статевих органів

\begin{tabular}{|c|c|c|c|c|c|c|}
\hline Piк & До 1993 & 1993-1998 & 1998-2003 & $2003-2008$ & 2008-2013 & 2013-2018 \\
\hline $\begin{array}{l}\text { Число хворих з вперше діагностованим раком зо- } \\
\text { внішніх статевих органів, абс. }\end{array}$ & 68 & 85 & 125 & 98 & 141 & 39 \\
\hline $\begin{array}{l}\text { Летальність пацієнтів з раком зовнішніх статевих } \\
\text { органів, абс. }\end{array}$ & 3 & 26 & 76 & 64 & 90 & 32 \\
\hline Рівень загальної летальності (\%) & 4,4 & 30,6 & 60,8 & 65,3 & 63,8 & 82.1 \\
\hline
\end{tabular}




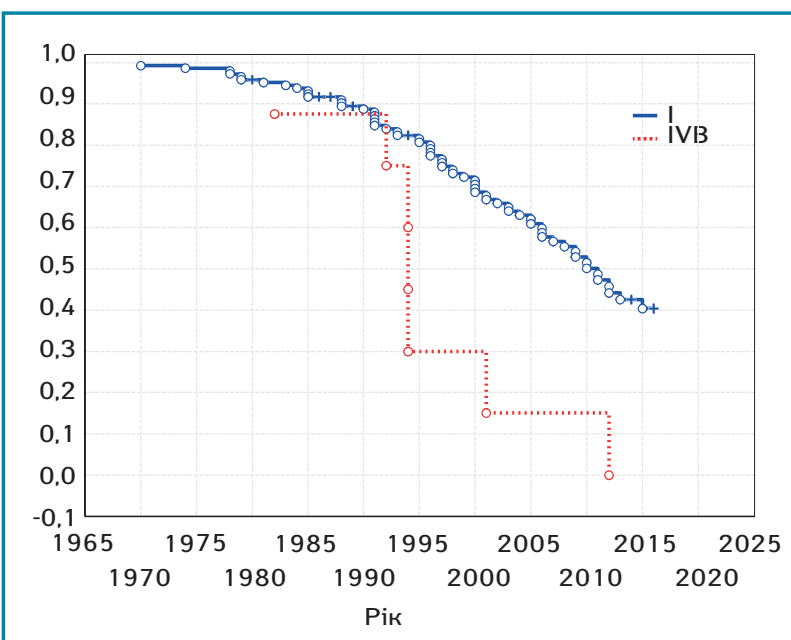

Рис. 1. Крива виживаності Каплана - Мейєра у пацієнтів з раком зовнішніх статевих органів при I та IVB стадіях за класифікацією FIGO

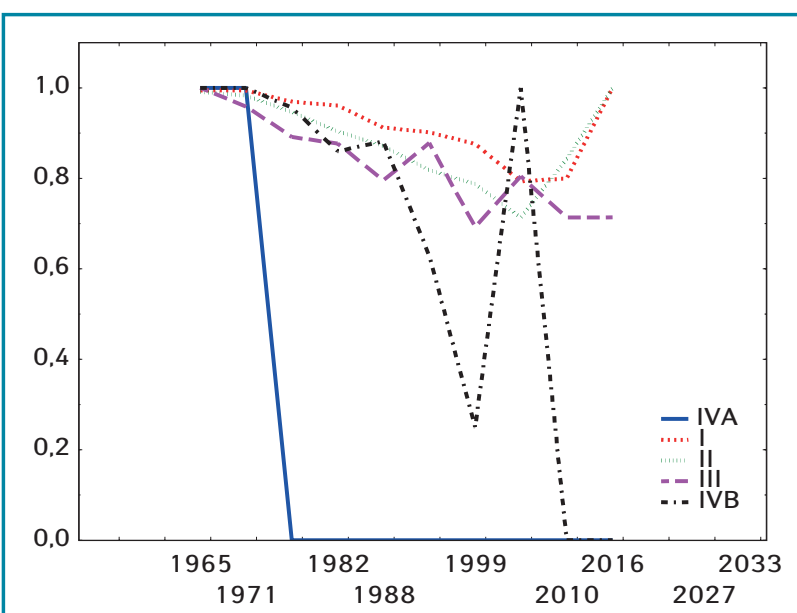

Рис. 2. Множинний аналіз виживаності при клінічних стадіях за класифікацією FIGO

ефективного лікування пацієнтів при зверненні не пізніше II стадії захворювання, що підтверджує провідне значення ранньої діагностики при цій патології.

Надалі було проведено аналіз значень клінічних критеріїв T, N та М для прогнозування рівня смертності у пацієнтів 3 пухлинами зовнішніх статевих органів (табл. 6-11).

Значний приріст летальності за критерієм Т відмічено при переході до Т3 та Т4 (74,4 та 100,0\%). При цьому смертність упродовж 25-річного ретроспективного спостереження при переході від критерію Т1 до Т2 зростала на 12,0\% (див. табл. 6).

Виявлено лінійну залежність при переходах Т2 - Т3 T4 (OR - 10,1, 14,0 та 18,0 відповідно, $\chi^{2}-12,07, \mathrm{p}=0,001$, Мантеля - Хензеля $\left.-\chi^{2}-12,05, \mathrm{p}<0,001\right)$ (табл. 7).

У табл. 8 розглянуто рівень смертності у пацієнток з пухлинами зовнішніх статевих органів залежно від критерію $\mathrm{N}$.

Встановлено зростання частоти загальної летальності при N1 та N2. У той же час суттєвої різниці між N1 та N2 встановлено не було $(80,0$ та 81,5\%). Також слід звернути увагу на критерій NX, коли регіонарні лімфатичні вузли діагностично не оцінені. При цьому рівень летальності був на 12,0\% вищим, ніж при N0 (табл. 8).

Виявлено приріст ризику загальноӥ летальності при N1 (OR - 1,41) та N2 (OR - 1,44) стадіях та зниження вірогідності загальної смертності при стадії N0 (OR - 0,79, кумулятивне відношення шансів $(1,53[1,13-2,09])$, загальне відношення шансів $(1,49[1,12-1,99]))$ (табл. 9).
Таблиця 6. Рівень смертності у пацієнтів з пухлинами зовнішніх статевих органів впродовж 25-річного ретроспективного спостереження залежно від критерію Т за класифікацією TNM

\begin{tabular}{ccc}
\hline Стадія & Летальність, абс. & Летальність, $\%$ \\
\hline Tis & 1 & 5,6 \\
T1 & 51 & 43,9 \\
T1a & 1 & 10,0 \\
T1b & 9 & 23,1 \\
T2 & 160 & 55,9 \\
T3 & 67 & 74,4 \\
T4 & 2 & 100,0 \\
\hline
\end{tabular}

Таблиця 7. Відносна вірогідність та ризик загальної смертності у пацієнтів з пухлинами зовнішніх статевих органів упродовж 25-річного ретроспективного спостереження залежно від критерія Т за класифікацією TNM

\begin{tabular}{cccc}
\hline Стадія & OR & $\begin{array}{c}\text { COR } \\
{[95 \% \text { дl] }}\end{array}$ & $\begin{array}{c}\text { GOR } \\
{[95 \% \text { дl] }}\end{array}$ \\
\hline Tis & 1,0 & & \\
T1 & 7,9 & & 1,60 \\
T1a & 1,8 & 1,67 & {$[1,26-2,03]$} \\
T1b & 4,2 & {$[1,29-2,18]$} & \\
T2 & 10,1 & & \\
T3 & 14,0 & & \\
T4 & 18,0 & & \\
\hline
\end{tabular}

Таблиця 8. Рівень смертності у пацієнтів з пухлинами зовнішніх статевих органів упродовж 25-річного ретроспективного спостереження залежно від критерію $\mathrm{N}$ за класифікацією TNM

\begin{tabular}{ccc}
\hline Стадія & Летальність, абс. & Летальність, \% \\
\hline NX & 17 & 56,7 \\
N0 & 188 & 44,7 \\
N1 & 64 & 80,0 \\
N2 & 22 & 81,5 \\
\hline
\end{tabular}

Таблиця 9. Відносна вірогідність та шанси загальної смертності у пацієнтів з пухлинами зовнішніх статевих органів упродовж 25-річного ретроспективного спостереження залежно від критерію N за класифікацією TNM

\begin{tabular}{cccc}
\hline Стадія & OR & $\begin{array}{c}\text { COR } \\
{[95 \% \text { dl] }}\end{array}$ & $\begin{array}{c}\text { GOR } \\
{[95 \% \text { дl] }}\end{array}$ \\
\hline NX & 1,0 & & \\
N0 & 0,79 & 1,53 & 1,49 \\
N1 & 1,41 & {$[1,13-2,09]$} & {$[1,12-1,99]$} \\
N2 & 1,44 & & \\
\hline
\end{tabular}

Таблиця 10.Рівень смертності у пацієнтів з пухлинами зовнішніх статевих органів упродовж 25-річного ретроспективного спостереження залежно від критерію М за класифікацією TNM

\begin{tabular}{ccc}
\hline Стадія & Летальність, абс. & Летальність, \% \\
\hline MX & 10 & 66,7 \\
M0 & 251 & 49,6 \\
M1 & 30 & 83,3 \\
\hline
\end{tabular}

Таблиця 11. Відносна вірогідність та шанси загальної смертності у пацієнтів з пухлинами 3 СО впродовж 25-річного ретроспективного спостереження залежно від критерію М за класифікацією TNM

\begin{tabular}{cccc}
\hline Стадія & OR & $\begin{array}{c}\text { COR } \\
\text { [95\% ДI] }\end{array}$ & $\begin{array}{c}\text { GOR } \\
\text { [95\% ДI] }\end{array}$ \\
\hline MX & 1,0 & 1,34 & 1,34 \\
M0 & 0,74 & {$[0,86-2,08]$} & {$[0,92-1,95]$} \\
M1 & 1,25 & & \\
\hline
\end{tabular}

Дані дослідження рівня загальної летальності за критерієм М наведені в табл. 10-11.

Загальна смертність за наявності віддалених метастазів (M1) на 33,7\% перевищувала таку, що встановлена у разі відсутності метастазів (M0). Несприятливим був критерій МХ, коли з різних причин було неможливо оцінити наявність/відсутність віддалених метастазів. У даному разі загальна смертність була на 17,1\% вищою, ніж при М0.

На підтвердження важливості такого компонента, як достовірне виявлення віддалених метастазів, ми не виявили вірогідної різниці між критеріями МХ та М1 за аналізом ризику загальної смертності в тестах лінійних трендів (табл. 11). 
При множинному аналізі виживаності за методом Каплана - Мейєра, залежно від наявності/відсутності віддалених метастазів та метастазів у лімфатичні вузли, було отримано дані, що наведені на рис. 3-4.

Цікавим фактом було те, що останній пацієнт з наявністю МХ критерію «вибув» 3 дослідження ще в часовий проміжок 1995-2000 pр. Після 2000 р. таких пацієнтів, за результатами аналізу історій хвороб, що знаходилися в Національному інституті раку, не було. Можливо, даний факт слід сприймати як позитивні зрушення та підвищення якості діагностики. Зокрема, високоінформативним методом, що достовірно підтверджує наявність віддалених метастазів, є комп'ютерна томографія 3 контрастуванням. Цей метод на сьогодні впроваджений як обов'язкове дослідження для онкологічних пацієнтів.

За критерієм N, на жаль, ми не виявили подібної залежності. Було достовірно встановлено, що 25-річна виживаність пацієнтів з відсутністю метастазів у регіонарні лімфатичні вузли становила $30,0 \%$ (див. рис. 4). За наявності метастазів у лімфатичні вузли 3 одного боку $-20,0 \%, з$ двох боків - $0 \%$ (див. рис. 4). У той же час, на відміну від випадків метастазування у віддалені органи, пацієнти з критерієм NX включалися та вибували з дослідження впродовж усього періоду (до 2018 р.). Це виокремлює ще одну невирішену проблему онкогінекології-покращення діагностики метастазування в регіонарні лімфатичні вузли.

\section{ВИСНОВКИ}

1. Загальна смертність при ретроспективному аналізі пацієнтів з раком зовнішніх статевих органів при 25-річному спостереженні становила $52,2 \%$, середня виживаність $-6,0 \pm 4,48$ року.

2. Пацієнти зі стадіями IVA та IVB за шкалою FIGO характеризувалися найвищими показниками смертності; при IVB виключення з дослідження розподілено рівномірно на весь період спостереження, при IVA стадії пацієнти вибували за рахунок летальності вже на першому році спостереження.

3. Доведено приріст загальної виживаності після 2010 р. для I та II стадій захворювання. Значний приріст летальності за критерієм Т відмічено при переході до Т3 та Т4 (74,4 та 100,0\%), найнижчий показник загальної смертності відмічено при локальних пухлинах (Tis $-5,6 \%$ ).

4. Встановлено зростання частоти загальної летальності при $\mathrm{N} 1$ та $\mathrm{N} 2$ (80,0 та 81,5\% відповідно), порівняно з N0 $(44,7 \%, \mathrm{p}<0,05)$. При NX рівень летальності був на $12,0 \%$ вищим, ніж при N0.

5. Загальна смертність за наявності віддалених метастазів (M1) на 33,7\% перевищувала таку, що встановлена за відсутності метастазів (М0), 25-річна виживаність при М0 стадії раку вульви сягала 30,0\%, за наявності віддалених метастазів М1 - 0\%, $\mathrm{p}=0,048$ за критерієм логранк.

6. Після 2000 р. в Національному інституті раку було відмічено підвищення якості діагностики відносно критерію MX, проте за критерієм NX подібної залежності не виявлено.

\section{СПИСОК ВИКОРИСТАНОЇ ЛІТЕРАТУРИ}

1. Бохман, Я. В. (2002). Руководство по онкогинекологии. СПб.: Фолиант.

2. Худякова, М. А., Хаджимба, А. В., Данелян, К. Г., Гершфельд, Э. Д., Дигол, И. А., \& Максимов, С. Л. (2009). Факторы риска метастазирования рака вульвы в паховые лимфатические узлы. Сибирский онкологический журнал, 1, 210-211.

3. Федоренко, З. П., Гулак, Л. О., Михайлович, Ю. Й., Горох, Є. Л., Рижов, А. Ю., Сумкіна, О. В., \& Куценко, Л. Б. (2020). Рак в Україні, 2018-2019. Захворюваність, смертність, показники діяльності онкологічної служби/гол. ред. О. О. Колеснік. Бюлетень Національного канцер-реєстру України, 21,101.

4. Barlow, E. L., Kang, Y. J., Hacker, N. F., \& Canfell, K. (2015). Changing Trends in Vulvar Cancer Incidence and Mortality Rates in Australia Since 1982. International Journal of Gynecological Cancer, 25(9), 1683-1689. doi: 10.1097/IGC.0000000000000547.

5. Futagami, M., Yokoyama, Y., lino, K., Aoki, M., Shoji, T., Sugiyama, T., Mizunuma, H. (2015). Investigation of the clinicopathological features of squamous cell carcinoma of the vulva: a retrospective survey of the Tohoku Gynecologic Cancer Unit. International Journal of Clinical Oncology, 20(5), 1005-1011. doi: $10.1007 / \mathrm{s} 10147-015-0803-\mathrm{x}$.

6. Karam, A., \& Dorigo, O. (2012). Treatment outcomes in a large cohort of patients with invasive Extramammary Paget's disease. Gynecologic Oncology, 125(2), 346-351. doi: 10.1016/j.ygyno.2012.01.032.

7. Hacker, N. F., \& Barlow, E. L. (2015). Staging for vulvar cancer. Best Practice \& Research: Clinical Obstetrics \& Gynaecology, 29(6), 802-811. doi: 10.1016/j.bpobgyn.2015.01.004.

8. Te Grootenhuis, N. C., van der Zee, A. G., van Doorn, H. C., van der Velden, J., Vergote, I., Zanagnolo, V., \& Oonk, M. H. (2016). Sentinel nodes in vulvar cancer: Longterm follow-up of the GROningen INternational Study on Sentinel nodes in Vulvar cancer (GROINSS-V) I. Gynecologic Oncology, 140 (1), 8-14. doi: 10.1016/j.ygyno.2015.09.077.

9. Kupets, R., Giede, K. C., Power, P., \& Agrawal, A. (2016). The Investigations Required Before Referring a Patient to a Gynaecologic Oncologist. Executive of the Society of Gynecologic Oncology of Canada. Journal of Obstetrics and Gynaecology Canada, 38(2), 164-167. doi: 10.1016/j.jogc.2015.12.016.

10. Khanna, N., Rauh, L. A., Lachiewicz, M. P., \& Horowitz'I. R. (2016). Margins for cervical and vulvar cancer. Journal of Surgical Oncology, 113(3), 304-309. doi: $10.1002 /$ jso. 24108

11. Koh, W. J., Greer, B. E., Abu-Rustum, N. R., Campos, S. M., Cho, K. R., Chon, H. S., ... Scavone, J. (2017). Vulvar Cancer, Version 1. 2017, NCCN Clinical Practice Guidelines in Oncology. Journal of the National Comprehensive Cancer Network, 15(1), 92-120. doi: 10.6004/jnccn.2017.0008.

12. Реброва О. Ю. (2004). Статистический анализ медицинских данных. Применение пакета прикладных программ STATISTICA. Москва: Медиа-сфера.

\section{Уровень летальности больных \\ с опухолями наружных половых органов при ретроспективном 25-летнем наблюдении, роль клинического стадирования в прогнозировании отдаленной летальности \\ А.А. Самохвалова, К.В. Копчак, С.В. Неспрядько, Н.П. Цип, В.С. Свинцицкий}

Национальный институт рака, Киев

Резюме. Материал и методы исследования. Статья базируется на 25-летнем ретроспективном наблюдении и посвящена анализу уровня летальности среди пациентов с опухолями наружных половых органов, прогнозированию отдаленной летальности в зависимости от клинических особен- 
ностей опухолей. Работа проводилась на базе Национального института рака с включением изучения 557 историй болезней пациентов за период 1993-2018 гг. Результаты. Средняя выживаемость составила $6,0 \pm 4,48$ года. Высокими показателями общей смертности характеризовались пациенты с IVA и IVB стадиями заболевания по шкале Международной федерации гинекологии и акушерства (International Federation Gynecology and Obstetrics - FIGO, при IVB стадии исключения из исследования были распределены равномерно в течение всего периода наблюдения, при IVA стадии пациенты выбывали за счет летальности уже в первый год. Доказан прирост общей выживаемости после 2010 г. для I и II стадий заболевания. Значительный прирост летальности по критерию Т выявлен при переходе к Т3 и Т4 (74,4 и 100,0\% соответственно), самый низкий показатель общей смертности отмечен при локальных опухолях (Tis - 5,6\%). Установлено повышение частоты общей летальности при N1 и N2 (80,0 и $81,5 \%$ соответственно) по сравнению с $\mathrm{N} 0(44,7 \%, \mathrm{p}<0,05)$, при NX уровень летальности был на $12,0 \%$ выше, чем при критерии N0. Выводы. Общая смертность при наличии отдаленных метастазов (M1) на 33,7\% превышала таковую, установленную при отсутствии метастазов (М0). После 2000 г. в Национальном институте рака было отмечено повышение качества диагностики относительно критерия МX, однако по критерию NX улучшения качества диагностики не выявлено.

Ключевые слова: опухоли наружных половых органов; клиническое стадирование; отдаленная летальность; прогноз.

\section{Level of lethality of patients with external genital tumors at retrospective 25-year-old observation, the role of clinical condition}

O.O. Samokhvalova, K.V. Kopchak, S.V. Nespryadko, N.P. Tsip, V.S. Svintsitsky

National Cancer Institute, Kyiv

Materials and methods. The results of the article are based on 25-years retrospective observation and present total mortality rate in patients with external genital tumors. It also present the prognosis of totat lethality, depending on the clinical staging. The research is provided in National Cancer Institute, and included 557 case hystories between 1993-2018 years. Results. The mean survival rate is $6.0 \pm 4.48$ years. The highest level of total mortality were set in patients with IVA and IVB FIGO stages. At the patients with IVB stage total morthality was evenly distributed during all observation period; patients with IVA stage have been eliminated from observation during first year. It has been set the increasing of total survival after 2010 in patients with 1st and 2nd stages of external genital tumors. Significantly increase in mortality by criterion $\mathrm{T}$ was noted between T3 vs T4 criterions (74.4 and $100.0 \%$ ), the lowest overall mortality rate was observed in local tumors (Tis $-5.6 \%$ ). The increasing of total lethality was observed for $\mathrm{N} 1$ and $\mathrm{N} 2$ criterions ( 80.0 and $81.5 \%)$, vs $\mathrm{N} 0(44.7 \%$, $\mathrm{p}<0.05$ ). In NX stage, the mortality rate was in $12.0 \%$ higher vs $\mathrm{N} 0$ criterion. Conclusion. The total mortality in patients with distant metastases (M1) was on $33.7 \%$ more, than at women with M0 stage. After year 2000, in National Cancer Institute, it was set the improvement of diagnostic managment and reliable decrease of clinical cases with MX criterion, but unreliable changes of clinical cases with NX criterion.

Key words: external genital tumors; long-term morthality; clinical staging; prognosis.

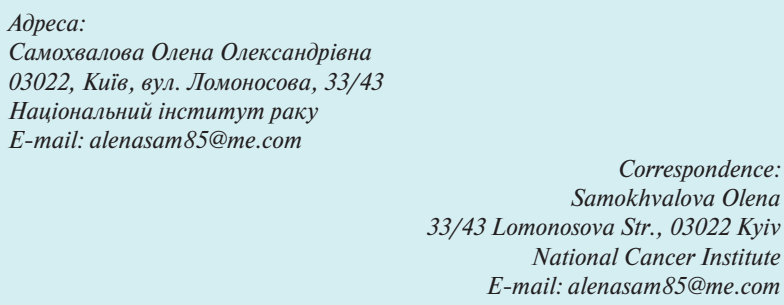

